\title{
PENDAMPINGAN PENGAJARAN BAHASA INGGRIS DI PANTI ASUHAN BUDI LUHUR KABUPATEN ACEH TENGAH
}

\author{
Khoiriyah Shofiyah Tanjung dan Nurliana \\ Fakultas Tarbiyah dan Fakultas Dakwah IAIN Takengon \\ E-mail :shofee_niez@yahoo.co.id,nurlianajufrizal@gmail.com
}

\begin{abstract}
ABSTRAK
Bahasa Inggris adalah salah satu bahasa internasional yang harus dikuasai oleh masyarakat dunia. Namun dalam pembelajarannya, menguasai bahasa Inggris tidaklah mudah. Beberapa faktor yang menyulitkan dalam pembelajaran bahasa Inggris adalah perbedaan pelafalan huruf dalam bahasa Inggris dan bahasa Indonesia, banyaknya kosa kata yang harus dihafal serta ketidakkonsistenan pelafalan huruf. Faktor-faktor tersebut menjadi sandungan bagi banyak orang dalam mempelajari bahasa Inggris. Tidak terkecuali anak-anak di Panti Asuhan Budi Luhur di Kabupaten Aceh Tengah. Dengan alasan tersebut, penulis melaksanakan pengabdian dengan mendampingi anak-anak Panti Asuhan belajar bahasa Inggris. Pengabdian tersebut dilaksanakan secara terjadwal dengan melakukan tiga stratgi; pembelajaran bahasa Inggris dengan materi yang disiapkan oleh pengabdi, membantu menyelesaikan pekerjaan rumah (PR) dan memberikan games bahasa Inggris. Hasil pengadian menunjukkan bahwa anak-anak Panti Asuhan Budi Luhur merasa terbantu dan antusias dalam belajar bahasa Inggris.
\end{abstract}

Kata Kunci: Pendampingan, Pengajaran, Bahasa Inggris, Panti Asuhan

\begin{abstract}
English is one of the international languages that must be mastered by the world community. However, in learning, mastering English is not easy. Some factors that make it difficult to learn English are the differences in the pronunciation of letters in English and Indonesian, the large number of vocabulary that must be memorized and the inconsistency of the pronunciation of letters. These factors become stumbling blocks for many people in learning English. The children at the Budi Luhur Orphanage in Central Aceh Regency were no exception. For this reason, the authors carry out the service by assisting the orphanage children to learn English. The service is carried out on a scheduled basis by carrying out three strategies; learning English with materials prepared by the servant, helping to complete homework (PR) and providing English games. The results showed that the children of the Budi Luhur Orphanage felt helped and were enthusiastic about learning English.
\end{abstract}

Keyword: Mentoring, Teaching, English, Orphanage

\section{PENDAHULUAN}

Mendapatkan pendidikan,
adalah hak setiap warga Negara
Indonesia, seperti yang tertuang dalam
Undang-Undang Dasar 1945 Pasal 31

ayat (1) menyatakan bahwa "Setiap warga negara berhak mendapat pendidikan." Namun fakta dilapangan berbicara lain, tidak semua orang, khususnya penduduk usia sekolah 
mendapatkan kesempatan untuk untuk memberikan pelayanan memperoleh pendidikan yang layak. kesejahteraan sosial pada anak telantar Dari data yang dimiliki Tim Nasional Percepatan Penanggulangan Kemiskinan (TNP2K), jumlah anak usia 7-12 tahun di Indonesia yang tidak bersekolah berada di angka 1.228 .792 anak. Untuk karegori usia 13-15 tahun di 34 provinsi, jumlahnya 936.674 anak. Sementara usia 16-18 tahun, ada $2,420,866$ anak yang tidak bersekolah. Sehingga secara keseluruhan, jumlah anak Indonesia yang tidak bersekolah mencapai 4.586.332. (Tempo, 29 Juli 2019)

Sebagaian anak-anak yang kurang beruntung ini adalah anak-anak yang terkendala biaya dan anak yatim piatu. Anak-anak tersebut sebagian kecilnya tinggal di Panti Asuhan, baik yang milik Negara ataupun swasta. Namun, meski dari segi tempat tinggal mereka telah terpenuhi, sebagian besar masih belum mendapatkan pendidikan yang optimal. Hal ini dikarenakan tidak semua panti asuhan memiliki dana yang cukup untuk memelihara anak-anak tersebut.

Menurut Depsos RI (Astama: 2015), Panti Sosial Asuhan anak adalah suatu lembaga usaha kesejahteraan sosial yang mempunyai tanggung jawab dengan melaksanakan penyantunan dan pengentasan anak telantar, memberikan pelayanan pengganti orang tua/wali anak dalam memenuhi kebutuhan fisik, mental dan sosial kepada anak asuh sehingga memperoleh kesempatan yang luas,tepat dan memadai bagi pengembangan kepribadianya sesuai dengan yang diharapkan sebagai bagian dari generasi penerus cita- cita bangsa dan sebagai insan yang akan turut serta aktif dalam bidang pembangunan nasionale. Menurut Gospor Nabor (Bardawi Barzan:1999, Hakim: 2017): "Panti asuhan adalah suatu lembaga pelayanan sosial yang didirikan oleh pemerintah maupun masyarakat, yang bertujuan untuk membantu atau memberikan bantuan terhadap individu, kelompok masyarakat dalam upaya memenuhi kebutuhan hidup". Menurut KBBI Panti asuhan adalah rumah tempat memelihara dan merawat anak yatim atau yatim piatu.

Di Kabupaten Aceh Tengah, terdapat beberapa Panti Asuhan yang menampung anak-anak yatim. Panti tersebut sebagian adalah dikelola oleh pribadi dan sebagian yang lain dikelola oleh pemerintah. Salah satu panti 
asuhan yang dikelola oleh pemerintah adalah Panti Asuhan Budi Luhur. Di Panti Asuhan Budi Luhur, latar belakang pendidikan anak-anaknya berbeda-beda, dimulai dari sekolah dasar sampai sekolah menengah atas.

Selain factor biaya dan ketiadaan orang tua, factor lain yang mempengaruhi pendidikan adalah factor akademik. Banyak anak-anak, khususnya yang tinggal di Panti Asuhan memiliki emampuan akademik yang cenderung menengah kebawah, karena ada sebagian anak yang sudah kelas 5 sekolah dasar atau pun SMP masih belum bisa membaca. Kemampuan berbahasa Indonesia mereka pun masih rendah karena bahasa ibu masih lebih mendominasi. Hal ini peneliti dan kawan-kawan pengabdi temukan di Panti Asuhan Budi Luhur.

Sebagian besar anak-anak Panti terkendala untuk memahami pelajaran yang mereka dapatkan disekolah, sehingga menurunkan minat mereka untuk belajar. Salah satu mata pelajaran yang dianggap sulit bagi anak-anak adalah bahasa Inggris. Meskipun, Bahasa Inggris telah diajarkan sejak sekolah dasar hingga perguruan tinggi. Namun tetap saja, kemampuan bahasa Inggris orang Indonesia masih kalah jauh dari negara tetangga, seperti Singapura dan Malaysia. Menurut EF English Proficiency Index tahun 2018, peringkat kemahiran bahasa Inggris orang Indonesia malah turun dari tahun 2017 yaitu diposisi 51 dari 32, peringkat ini diambil dari 88 negara di Asia. Masalah utama dalam pembelajaran bahasa Inggris adalah pembelajaran yang menoton sehingga pelajar tidak merasa tertarik ataupun malas untuk mempelajarinya. Sarana dan prasarana yang memadai juga sangat membantu dalam pembelajaran bahasa Inggris seperti audio dan televisi karna dengan kedua sarana tersebut siswa dapat lebih mudah mendengarkan dan meniru penutur asli bahasa Inggris tersebut. Namun, tidak semua sekolah atau lembaga memiliki sarana yang bagus untuk pembelajaran, salah satunya adalah panti Asuhan. Hal ini lah kemudian yang menjadi masalah dalam pembelajaran bahasa Inggris anak-anak panti Budi Luhur. Anak-anak panti cenderung malas untuk beajar bahasa Inggris, karena menurut mereka bahasa Inggris itu sulit dan banyak kata-kata yang susah untuk diucapkan.

Bahasa Inggris dianggap susah karena terdapat sangat banyak kosakata dalam Bahasa Inggris yang sering kita 
gunakan dalam kehidupan sehari-hari yang berasal dari kata-kata dalam Bahasa Latin, Bahasa Yunani kuno, dan bahkan juga dari beberapa bahasa lainnya di Eropa. Hal ini menyebabkan jumlah kosakata dalam Bahasa Inggris berkembang sangat pesat bahkan hingga saat ini. Bahkan menurut penelitian yang dilakukan oleh Oxford, hampir setiap 90 menit sekali ditemukan satu kata baru dalam Bahasa Inggris. Hal ini tentunya sangat sulit bagi pembelajar bahasa baru seperti kita, mengingat pentingnya penguasaan kosakata dalam penguasaan suatu bahasa, jika kosakata bahasa tersebut berkembang begitu pesat, tentunya sangat sulit bagi kita untuk mengikuti perkembangan itu

Yang kedua adalah pola kata bahasa Inggris yang tida konsisten, misalnya kata untuk penyanyi adalah vocalist, orang yang memainkan gitar adalah guitarist, namun orang yang memainkan drum adalah drummer. Hal inilah yang biasanya membuat bingung anak-anak dalam belajar bahasa Inggris. Alasan yang ketiga adalah banyaknya pengecualian dalam tata bahasa, misalnya perubahan kata kerja dari bentuk present ke past, tidak semua menambahkan ed dibelakang kata. Hal ini tentu saja membingungkan bagi anak-anak yang memang tidak pernah belajar bahasa Inggris. Yang terakhir adalah, urutan penempatan kata yang membingungkan. Dalam bahasa Indonesia kata benda selalu berada di depan kata sifat, namun dalam bahasa Inggris, sebaliknya kata sifat berada di depan kata benda. Jadi, ketika ingin menyebutkan kata hitam, maka yang pertama kali disebutkan adalah hitamnya, baru bukunya, black book.

Hal inilah yang menjadi dasar pengabdi untuk melakukan pendampingan di Panti Asuhan. Dalam Islam sendiri, memelihara anak yatim adalah salah satu ibadah yang utama, sehingga terdapat 22 ayat yang menyebutkan tentang anak anak yatim. Seperti yang disebutkan dalam Surah Al-Maun "Tahukah kamu (orang) yang mendustakan agama?Maka itulah orang yang menghardik anak yatim." (QS.107:1-2) serta surah Annisa ayat 36 yang artinya "Sembahlah Allah dan janganlah kamu mempersekutukan Nya dengan sesuatupun. Dan berbuat baiklah kepada orangtua ibu bapak, karib kerabat, anak-anak yatim, dan orangorang miskin. Dengan latar belakang diatas pengabdi ingin melakukan pendampingan pengajaran bahasa Inggris di Panti Asuhan Budi Luhur. 


\section{KHALAYAK SASARAN}

Sasaran dampingan yaitu anakanak yang dibina Panti Asuhan Budi Luhur. Mereka diasramakan di panti asuhan namun menempuh pendidikan formal di luar panti asuhan.Diantara mereka ada yang menempuh pendidikan di SD/MI, SMP/MTs, dan SMA/MA. Setelah melaksanakan kegiatan belajar mengajar di sekolah pada pagi hingga siang hari, anak-anak kembali istirahat di asrama panti asuhan. Pengurus panti asuhan selain menyiapkan kebutuhan sandang dan pangan mereka, juga menyiapkan ustaz dan ustazah untuk mendampingi mereka melaksanakan kewajiban keagamaan mereka hanya dalam hal membaca Al-Qur'an sedangkan untuk pembinaan akhlak dan menangani kesulitan pemahaman mereka ketika belajar di sekolah belum terfasilitasi dengan baik.

Pengabdian ini dilaksanakan di Panti Asuhan Budi Luhur, yang merupakan UPTD di bawah Dinas Sosial, Tenaga Kerja dan Transmigrasi Kabupaten Aceh Tengah. Jalan Lebe Kader, Kec. Bebesen, Kab. Aceh Tengah. Panti Asuhan Budi Luhur didirikan setelah 3 tahun Indoesia merdeka atau pada tahun 1948. Pada awalnya Panti Asuhan ini bernama Asrama Penyantunan Fakir Miskin dan Yatim Piatu. Panti Asuhan Budi Luhur, pertama kali dibangun oleh para tokoh agama Aceh Tengah dibagian Baitulmal dengan tujuan untuk memelihara anakanak yatim para pejuang yang gugur di medan perang. Panti Asuhan ini juga berfungsi sebagi tempat untuk menampung pengungsi yang dating dari Sumatera Utara yang datang dari jalur Berastagi, Kabanjahe, Kotacane dan Blang Kejeren pada saat perang sekutu pada tahun 1948 dan 1949.

Panti Asuhan Budi Luhur mempunyai prinsip menyantuni, membina dan mengembangkan potensi anak yatim piatu di Kabupaten Aceh Tengah. Adapun visi Panti Asuhan Budi Luhur adalah menyantuni dan membina anak yatim piatu menjadi anak yang berpendidikan, berprestasi dan berakhlakul karimah. Untuk mewujudkan visi dan misi tersebut Panti Asuhan Budi Luhur disokong oleh dana bantuan dari Kabuapaten Aceh Tengah juga zakat dan sedekah dari masyarakat.

\section{METODE PELAKSANAAN}

Pendampingan mata pelajaran bahasa Inggris dilaksanakan dengan dua 
strategi. Strategi pertama dimana pengabdi menyiapkan materi umum dan disampaikan kepada seluruh anak-anak dampingan. Kedua, pengabdi memberikan layanan konsultasi materi bahasa Inggris sekolah berdasarkan kebutuhan masing-masing dan menyesuaikan materi yang mereka pelajari di sekolah.

Sebelumnya, pengabdi juga membagi kelompok anak-anak panti asuhan berdasarkan kelompok sekolah mereka, agar materi yang diberikan tidak tumpang tindih. Ada tiga kelompok sasaran: kelompok anak-anak SD, kelompok anak-anak SMP dan kelompok anak-anak SMA. Setiap akhir sesi pendampingan, pengabdi juga memberikan permainan (games) dalam pembelajaran bahasa inggris.

\section{HASIL DAN PEMBAHASAN}

Pada pertemuan pertama tanggal 13 Januari 2019, Pengabdi memberikan layanan konsultasi materi bahasa Inggris sekolah berdasarkan kebutuhan masing-masing dan menyesuaikan materi yang mereka pelajari di sekolah. Siswa dikelompokkan berdasarkan jenjang pendidikan dan kelas. Selanjutnya siswa pada masing-masing kelompok menyampaikan materi bahasa
Inggris yang sedang mereka pelajari di sekolah. Pengabdi selanjutnya memberi penjelasan untuk materi masing-masing kelompok secara bergantian. Setelah memberi penjelasan pada suatu kelompok selanjutnya diberikan latihan pada kelompok tersebut dan dilanjutkan ke kelompok yang lain. Setelah semua kelompok tercover dilanjutkan dengan evaluasi latihan masing-masing kelompok. Sesi diakhiri dengan konsultasi tugas bagi siswa yang sulit memahami tugas bahasa Inggris yang mereka dapat dari sekolah.Konsultasi tugas dilakukan dengan pendekatan scaffolding dimana siswa tidak diberi jawaban atas tugas mereka secara langsung tetapi diarahkan sehingga menemukan penyelesaian sendiri.

Dalam pertemuan ini, terdapat 3 materi bahasa Inggris yang diajarkan atas permintaan anak-anak panti asuhan yaitu If Clause (Untuk jenjang SMA), Question Tag to untuk jenjang SMP dan Vocabulary tentang animal untuk Jenjang SD

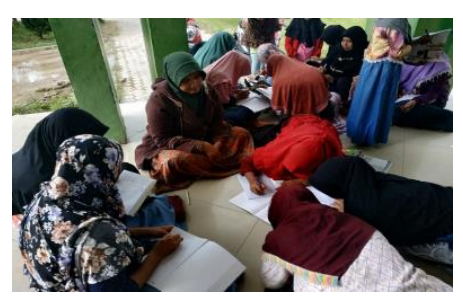

Gambar 1. Pendampingan dilaksanakan dengan pendekatan yang berdasarkan kebutuhan anak 
Pertemuan kedua pada hari jumat 18 Oktober 2019, pengabdi melaksanakan pendampingan dengan melakukan pendekatan yang berbeda, yaitu dengan menyiapkan materi bahasa Inggris terlebih dahulu, lalu diajarkan kepada semua anak dalam jenjang tertentu dalam waktu yang sama. Pendekatan ini dilaksanakan untuk memperoleh pemahaman yang sama dalam sebuah materi. Pada pertemuan ini, pengabdi menjelaskan tentang parts of speech yang menjadi dasar dalam belajar bahasa Inggris juga tentang vocabulary. Parts of Speech yang diajarkan adalah Adjective

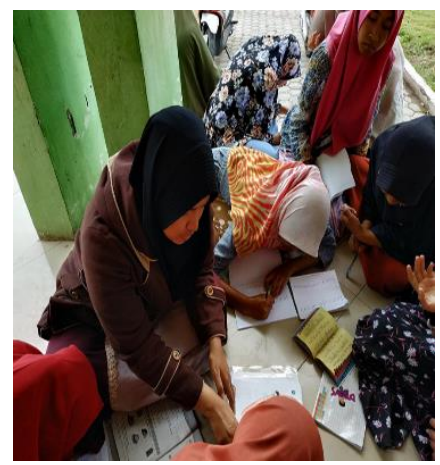

Gambar 2: Pendekatan dengan mempersiapkan materi terlebih dahulu Pertemuan ke 3 tanggal 6 Desember 2019, pengabdi melakukan games bahasa Inggris. Kegiatan ini dilaksanakan untuk menarik minat anak-anak dalam belajar bahasa Inggris. Kegiatan ini sering dilakukan untuk mengatisipasi kebosanan anak-anak dalam belajar. Selain memperoleh ilmu, dengan kegiatan ini psikis anak-anak juga menjadi ceria karena diselingi senda gurau dengan para pengabdi lainnya. Ada 3 games yang dilaksanakan pada pertemuan ini, yaitu Vocabulary Games dan Tongue Twister

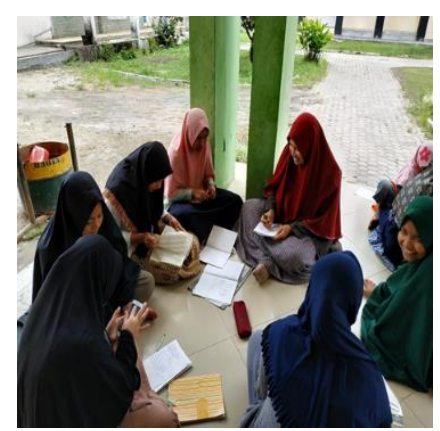

Gambar 3: Pengabdian dengan diselingi Games

Kegiatan pendampingan ini merupakan kegiatan yang telah rutin dan berkelanjutan dilaksanakan sejak tahun 2015. Kegiatan ini diprogramkan per semester/per enam bulan. Hasil dari kegiatan ini dapat dilihat dari antusiasme siswa yang tidak pernah surut sejak kegiatan ini pertama kali dilaksanakan. Beberapa anak dampingan dari Panti Asuhan Budi Luhur melanjutkan pendidikan di perguruan tinggi tidak terkecuali di STAIN Gajah Putih Takengon.

Ketercapaian kegiatan pada periode ini dapat dilihat dari anak-anak dampingan dapat memahami materi bahasa Inggris sekolah yang disampaikan pada sesi bahasa Inggris. Hal ini dilihat dari hasil kerja latihan 
bahasa Inggris yang diberikan setiap sesi dampingan mata pelajaran bahasa Inggris berlangsung.

\section{KESIMPULAN}

Berdasarkan hasil pengabdian ini maka disimpulkan, anak-anak panti asuhan sebagai dampingan terbantu dalam memahami materi sekolah terkhusus materi bahasa Inggris sekolah yang dibahas pada sesi dampingan mata pelajaran bahasa Inggris.

Melihat antusiasme anak-anak panti ketika ada jadwal pengadian, meningkatkanya pemahaman mereka terhadap materi-materi yang diajarkan serta manfat kegiatan yang anak-anak panti dapatkan maka kedepannya, kegiatan ini akan terus dilaksanakan pada masa-masa yang akan datang.

Berdasarkan hasil pengabdian ini maka direkomendasikan antara lain:

1. Lebih banyak lagi muncul komunitas-komunitas yang peduli terhadap pendidikan anak-anak yang dibina di lembaga panti asuhan terkhusus di Kabupaten Aceh Tengah.

2. Kegiatan pada priode selanjutnya lebih bervariasi dan dapat ditambahkan dengan kegiatan outbond sehingga menyegarkan motivasi anak dampingan.

\section{DAFTAR PUSTAKA}

$\mathrm{ABC}$,

https://www.tempo.co/abc/4460/p artisipasi-pendidikan-naik-tapijutaan-anak-indonesia-masihputus-sekolah, diakses tanggal 29 Juli 2019

Astama, F.Y. 2015. Panti asuhan anak terlantar di kabupaten Magelang. http://ejournal.uajy.ac.id/7730/1/TA0136 $\underline{44 . p d f}$

Dahuri, D. 2019. Indeks Kemampuan Bahasa Inggris Orang Indonesia Nomor 61. https://mediaindonesia.com/huma niora/277217/indeks-kemampuanbahasa-inggris-orang-indonesianomor-61

Fitri, J.A. 2016. Perkembangan panti asuhan budi luhur di Kabupaten Aceh Tengah 1948-2014. https://etd.unsyiah.ac.id/baca/notf ound.php?biblio_id=21469

Hakim, M.S.A. 2017. Peran Panti sosial asuhan anak dalam mengembangkan karakter peduli social anak. http://repository.unpas.ac.id/3058 7/4/12\%20BAB\%20I.pdf

http://kbbi.web.id

www.ef.co.id 